Original Contribution

\title{
EFFECTS OF OLIVE VARIETIES ON A- AND B-GLUCOSIDASE ACTIVITIES IN THE LARVAE OF BACTEROCERA OLEAE GMELIN (DIPTERA: TEPHRITIDAE)
}

\author{
S. Delkash-Roudsari ${ }^{1}$, A. Zibaee ${ }^{1 *}$, M. R. Abbci-Mozddehi ${ }^{2}$ \\ ${ }^{1}$ Department of Plant Protection, Faculty of Agricultural Sciences, University of Guilan, Rasht, Iran \\ ${ }^{2}$ Agricultural and Natural Resources Center, Rasht, Iran
}

\begin{abstract}
The olive fruit fly, Bacterocera oleae Gmelin (Diptera: Tephritidae) is a serious pest of olive around the world. In the current research, digestive glucosidases were studies in the alimentary canal of the last larval instar. The specific activity of $\alpha$ - and $\beta$-glucosidases were 0.077 and $0.023 \mathrm{U} / \mathrm{mg}$ protein in soluble fraction. Results showed that optimal activities of $\alpha$ - and $\beta$-glucosidases were at $\mathrm{pHs} 5-6$ and temperatures of $45^{\circ} \mathrm{C}$ and $25{ }^{\circ} \mathrm{C}$ for $\alpha$ - and $\beta$-glucosidases, respectively. $\mathrm{Ca}^{2+}, \mathrm{Cu}^{2+}, \mathrm{Fe}^{2+}, \mathrm{Na}^{+}$and $\mathrm{Zn}^{2+}$ significantly increased activity of $\alpha$-glucosidase but $\mathrm{K}^{+}$and $\mathrm{Mg}^{2+}$ had the opposite effects. Meanwhile, $\mathrm{Cu}^{2+} \mathrm{K}^{+}$and $\mathrm{Na}^{+}$increased $\beta$-glucosidase activity and other ions decreased it in the gut of $B$. oleae. Among used specific inhibitors, Phananthroline and DTC significantly decreased activity of $\alpha$ - glucosidases but EGTA and EDTA decreased $\beta$-glucosidase activity. Other compounds had no statistical effects on enzymatic activity. Kinetic parameters of $\alpha$ - and $\beta$-glucosidases showed a $K_{m}$ of 4.26 and $0.84(\mathrm{mM})$, respectively. Also maximal velocities $\left(V_{\max }\right)$ were found to be 0.21 and $0.11 \mathrm{U} / \mathrm{mg}$ protein. The highest activities of $\alpha$ and $\beta$-glucosidase was found in Frangivento and Fishomi varieties but the enzymatic activities significantly decreased in the larvae fed on Amigdalifolia, Zard and Conservalia varieties. Understanding of digestive enzyme properties, particularly the effect of inhibitors on enzymatic activity and physiology of insects, could be useful to reach safe and useful controls of insect pests before achieving to resistant varieties.
\end{abstract}

Key words: Bacterocera oleae, $\alpha$-glucosidase, $\beta$-glucosidase, different varieties

\section{INTRODUCTION}

The olive fruit fly Bacterocera oleae Gmelin (Diptera: Tephritidae) is a serious pest of olive in Africa, Southern Europe, India, western Asia and California $(1,2)$. The pest has been introduced to north of Iran since 2004 and to date it causes severe damages to olive production (3). Larvae feed on olive fruits and cause loss of the olive crop by tunneling and feasibility of pathogen entrances (1). Management of olive fruit fly rely on insecticides in bait sprays, trapping of adult flies, pheromone and biological control (4).

Polysaccharides like starch in plant cells and glycogen in animal tissues have important roles

*Correspondence to: Arash Zibaee Ph. D, Assistant Professor of Insect Physiology, Faculty of Agricultural Sciences, University of Guilan, Rasht, Iran, 416351314. Phone:+98-0131-6690485, Fax: +96-0131-6690281 in physiological processes so their utilization is critical for insects. Digestion of carbohydrates is initiated by action of amylases prior to glycosidases (5). Insect's glucosidases are recruited to hydrolyze disaccharides and oligosaccharides extracted from hemicelluloses and cellulose (6). $\alpha$-Glucosidase (EC 3.2.1.20) catalyzes the hydrolysis of 1, 4- $\alpha$-glucosidic linkages lead to releasing $\alpha$-glucose. Also it hydrolyzes sucrose, maltose, maltodextrin and pNP- $\alpha$-Dglucopyranoside (5) The enzyme can be found in alimentary canal, salivary secretions of insects (7) and hypopharyngeal glands of some insects $(8,9), \alpha$-Glucosidase has been isolated and characterized in some insects such as Dysdercus peruvianus (Hemiptera: Pyrrhocoridae) (10), Sitophilus zeamais (Coleoptera: Curculionidae) (11), Apis mellifera (Hymenoptera: Apidae) (12) and Chilo suppressalis Walker (Lepidoptera: Pyralidae) 
(13) and it has shown properties such as molecular masses of $60-80 \mathrm{kDa}, \mathrm{pH}$ optima of 5-6.5 and $\mathrm{pI}$ values of range 5.0-7.2. The enzyme has been sequences in dipterans showing the invariant residues: Asp 123, His 128, Asp 206, Arg 221, Glu 271, His 296, and Asp 297 (14). These residues are the same as the active site of $\alpha$-amylase family, and the three residues Gly 69, Pro 77, and Gly 323 have the structural role for some $\alpha$-glucosidases (15). $\beta$-Glucosidase (EC 3.2.1.21; beta-D glucoside glucohydrolase) hydrolyzes $\beta 1$, 4- linkages, releasing $\beta$-Dglucose (9). Biochemical properties of insect $\beta$ glucosidases have been reported as molecular masses of $30-150 \mathrm{kDa}, \mathrm{pH}$ optima of 4.5-6.5, and $\mathrm{pI}$ values of 3.7-6.8. The enzyme has been isolated from midgut cells of Rhynchosciara Americana larvae (16), Tenebrio molitor L. (Coleoptera: Tenebrionidae) larvae (17), Rhynchophorus palmarum larvae (18) termites Macrotermes mulleri (19), Macrotermes bellicosus (20), Macrotermes subhyalinus (21), honey bees (22) and Chilo suppressalis Walker (Lepidoptera: Pyralidae) (13). Currently, $\beta$ glucosidase of Spodoptera frugiperda Hubner (Lepidoptera: Noctuidae) and T. molitor L. (Coleoptera: Tenebrionidae) have been sequenced $(17,23)$. The enzyme has two glutamic acid residues responsible for catalysis and a structure of (b/a)8-barrel. pKas of the nucleophile (Glu 399) and proton donor (Glu 187 ) in $S$. frugiperda are 4.9 and 7.5, respectively. In addition, it has been found that residue Glu 451 is a key residue to determine the enzymatic preference for glucosides versus galactosides $(17,23)$.

Because control of $B$. oleae is problematic due to activity of larvae in inner parts of the fruits, it can be a great model to design and develop physiological control approached like using genes encoding toxic molecules and inhibitors. Insect digestive enzymes have various properties and they could be used to design new strategies for insect control. In case, a comprehensive study has been initiated by the authors to complete understanding of digestive enzyme properties in larvae of B. oleae. In the first step, digestive $\alpha$-amylase of larvae were characterized and its inhibition was determined toward proteinaceous inhibitor (24). In this study, we attempted to biochemically characterization of $\alpha$ glucosidase and $\beta$-glucosidase from larvae of $B$. oleae via measuring $\mathrm{pH}$, temperature, effects of ions and inhibitors as well as kinetic parameters. Also, possible changes of the enzymatic activities were assessed followed by larval feeding on the twelve varieties of olive.

\section{MATERIAL AND METHODS}

\section{Insect rearing}

For glucosidase characterization, larvae were reared on the olive fruits of Arbequina variety in containers of $20 \times 12 \mathrm{~cm}$. Laboratory conditions were $25 \pm 1{ }^{\circ} \mathrm{C}, 70 \%$ of $\mathrm{RH}$ and 16L:8D. Rearing containers were daily checked and cleaned to remove any contaminations. To find effects of host plants, containers with fruits of twelve varieties (Amigdalifolia, Manzallina, Arbequina, Conservalia, Kalamata, Balidi, Zard, Roghani, Shengher, Mari, Fishomi, Frangivento and Coratina) were provided and allowed larvae separately to feed on each variety until $3^{\text {rd }}$ larval instar.

\section{Sample preparation and enzyme assays}

Third larval instars were separated from fruits, dissected under a stereomicroscope in ice cold saline solution $(\mathrm{NaCl}, 10 \mathrm{mM})$, digestive systems were removed and homogenized in distilled water (Equal portion w/v) using a hand-held glass homogenizer. Then, the samples were centrifuged at 13,000 rpm for 20 min at $4^{\circ} \mathrm{C}$. Supernatant was separated and kept at $-20{ }^{\circ} \mathrm{C}$ for subsequent experiments as the enzyme source.

\section{Preparation of membrane-bound fraction}

Membrane preparations were exposed from pellets of centrifuged digestive tract (see above) to Triton X-100 for $20 \mathrm{~h}$ at $4^{\circ} \mathrm{C}$, in a ratio of 10 mg of Triton X-100 per mg of protein. Samples were centrifuged at $13,000 \mathrm{rpm}$ for $20 \mathrm{~min}$ so that no sediment was visible at the end of process. Activity of the enzymes remains unchanged at $-20^{\circ} \mathrm{C}$ for periods of at least a month $(16,25)$.

\section{$\alpha$ - and $\beta$-glucosidase assay}

Activities of $\alpha$ - and $\beta$-glucosidases were measured according to a method described by Ferriera and Terra (16) with $p$-nitrophenyl- $\alpha$ Dglucopyranoside $(\mathrm{pN} \alpha \mathrm{G})$ and $p$-nitrophenyl- $\beta$ D-glucopyranoside (pN $\beta G)$ as substrates, respectively. Samples of soluble and membranebound fractions were incubated with $10 \mu \mathrm{L}$ of substrate and $40 \mu \mathrm{L}$ of universal buffer $(\mathrm{pH} 7)$. The absorbance was measured at $405 \mathrm{~nm}$ using a microplate reader after $10 \mathrm{~min}$ based on the preliminary incubation.

Effect of pH and temperature on $\alpha$ and $\beta$ glucosidase activity 
The effects of temperature and $\mathrm{pH}$ on activities of $\alpha$ and $\beta$-glucosidase were examined in the various $\mathrm{pH}$ and temperature ranges. Effect of temperature on $\alpha$ and $\beta$-glucosidase activities was determined by incubating the reaction mixture at $20-60^{\circ} \mathrm{C}$ for $30 \mathrm{~min}$ followed by measurement of the enzyme activity. The optimum $\mathrm{pH}$ for $\alpha$ and $\beta$-glucosidase was determined using the universal buffer in $\mathrm{pH}$ ranges of 3-12. Other steps were continued as described earlier.

Effect of different cations and inhibitors on $\alpha$ and $\beta$-glucosidase activity

Different concentrations of cations (1, 3 and 5 $\mathrm{mM})$ and inhibitors $(2,4,6,8$ and $10 \mathrm{mM})$ were assayed to find their effects on $\alpha$ and $\beta$ glucosidase activities in $B$. oleae larvae. Used cations were $\mathrm{Ca}^{2+}, \mathrm{Cu}^{2+}, \mathrm{Fe}^{2+}, \mathrm{K}^{+}, \mathrm{Mg}^{2+}, \mathrm{Na}^{+}$and $\mathrm{Zn}^{2+}$. Inhibitors were ethylenediamide tetraacetic acid (EDTA), ethylene glycol-bis ( $\beta$ aminoethylether) $\mathrm{N}, \mathrm{N}, \mathrm{N}-$, N-tetraacetic acid (EGTA), triethylenetetramine hexaacetic acid (TTHA), diethyldithiocarbamate (DTC), phenanthrolien. These compounds were added to the assay mixture, then incubation was continued for $10 \mathrm{~min}$ and absorbance was recorded at 405 nm using a microplate reader.

Kinetic parameters $\left(V_{\max }\right.$ and $\left.K_{m}\right)$ of $\alpha$ - and $\beta$ glucosidase in gut

Kinetic parameters of $\alpha$ - and $\beta$-glucosidases were determined using six different substrate concentrations $(0.5,1.2,3,4$ and $5 \mathrm{mM})$. The Michaelis constant $\left(K_{m}\right)$ and the maximum velocity $\left(V_{\max }\right)$ were estimated by Sigmaplot software after reading the absorbance followed by enzymatic assessments.
DELKASH-ROUDSARI S. et al.

Effect of different varieties on $\alpha$ - and $\beta$ glucosidases

$\alpha$ - and $\beta$-Glucosidases activities were assayed in the third larval instar reared on each olive variety including Amigdalifolia, Manzallina, Arbequina, Conservalia, Kalamata, Balidi, Zard, Roghani, Shengher, Mari, Fishomi, Frangivento and Coratina. Reaction mixture was $10 \mu \mathrm{L}$ of substrate, $40 \mu \mathrm{L}$ of universal buffer and 10 microlitre of the samples from each variety, separately.

\section{Protein concentration}

Protein concentrations were estimated as described by Lowry et al. [26], using bovine serum albumi as the standard.

\section{Statistical analysis}

All data were compared by one-way analysis of variance (ANOVA) followed by Tukey's test when significant differences were found at $p \leq$ 0.05 using SAS program.

\section{RESULTS \\ $\alpha$ - and $\beta$-glucosidase assay}

Results regarding activity localizations of glucosidases revealed the highest activities in soluble rather than membrane-bound fraction (Table 1). Also it was found that specific activities of $\alpha$ - and $\beta$-glucosidases in the digestive system of B.oleae larvae were 0.077 $\mathrm{U} / \mathrm{mg}$ protein and $0.023 \mathrm{U} / \mathrm{mg}$ protein in the last larval instar, respectively (Table1). The results indicated higher activity of glucosidases in soluble fraction by significant activity of $\alpha$ glucosidase in comparison with $\beta$-glucosidase (Table 1).

Table 1. The specific activities (mean \pm SE) of digestive in larvae of B.oleae.

\begin{tabular}{lll}
\hline & Soluble & Membrane \\
\hline$\alpha$-glucosidases (U/mg protein) & $0.225 \pm 0.035 \mathrm{a}$ & $0.042 \pm 0.026 \mathrm{~b}$ \\
$\beta$-glucosidases (U/mg protein) & $0.067 \pm 0.035 \mathrm{a}$ & 0 \\
Protein(U/mg/dl) & 0.994 & 1.126 \\
\hline
\end{tabular}

*.Statistical differences have been shown by asterisks (t-test, $p \leq 0.05$ ).

\section{Effect of $\mathrm{pH}$ and temperature on $\alpha$ - and $\beta$ - glucosidase activities}

The effect of $\mathrm{pH}$ on the hydrolytic activity against $\mathrm{pN} \alpha \mathrm{G}, \mathrm{pN} ß \mathrm{G}$ were assayed using wide range of values provided by universal buffer. The highest activities were observed at $\mathrm{pH}$ 5-6 for $\alpha$-glucosidase and 5 for $\beta$-glucosidases
(Figure 1). In both cases, enzymatic activity was elevated in acidic range then it sharply decreased (Figure 1). Also, the optimal temperature values for $\alpha$-glucosidase was found at $45^{\circ} \mathrm{C}$ and $25{ }^{\circ} \mathrm{C}$ for $\beta$-glucosidases (Figure 2). In other values, enzymatic activity was somehow equal (Figure 2). 


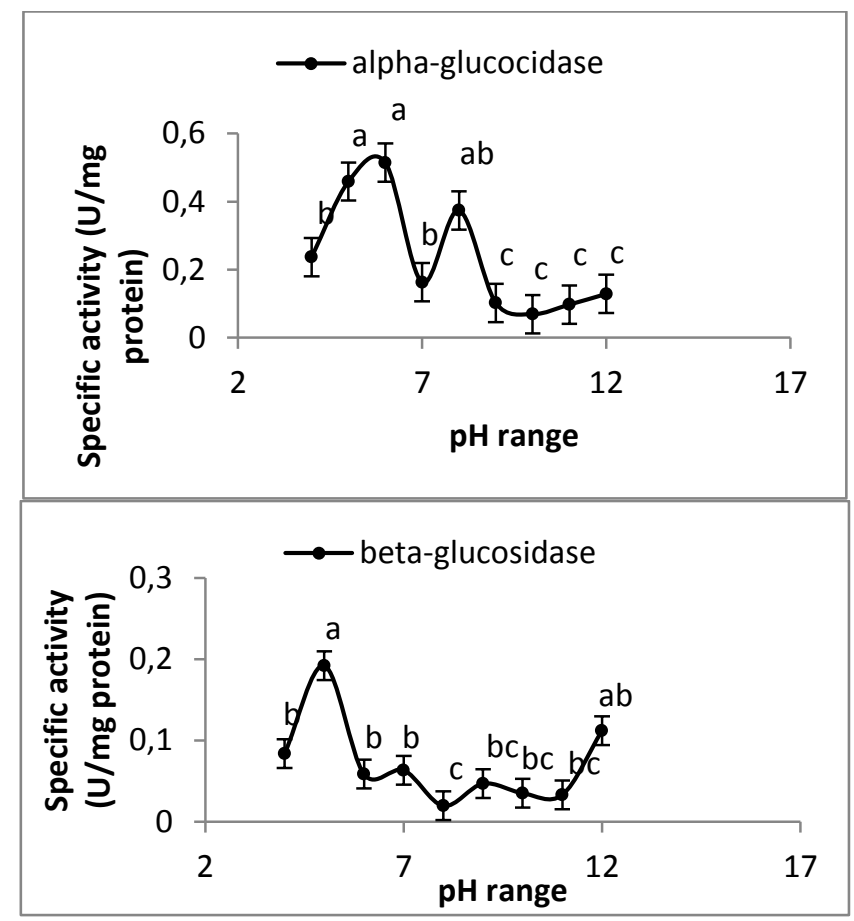

Figure 1. The effect of $\mathrm{pH}$ on the activities of $\alpha$ - and $\beta$-glucosidases extracted from the digestive system of B.oleae larvae. Statistical deifferences have been shown by various letters (Tukey's test, $p \leq 0.05$ ).

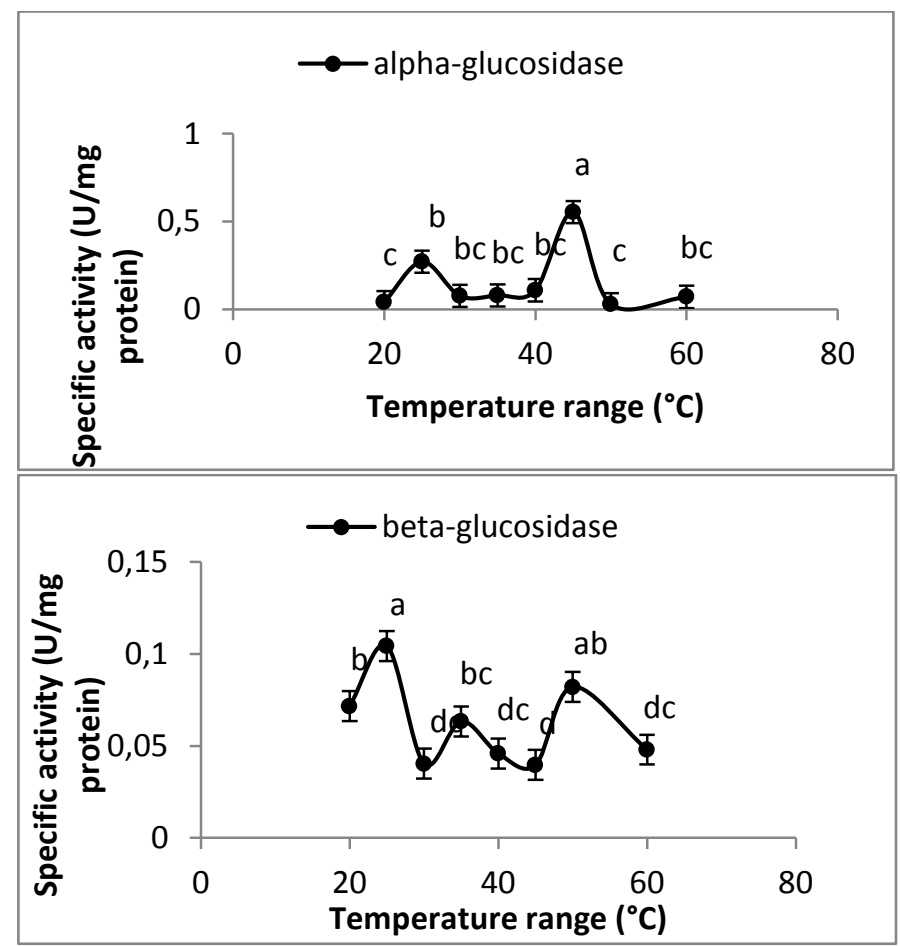

Figure 2. The effect of temperature on the activities of $\alpha$ - and $\beta$ - glucosidases extracted from the digestive system of B.oleae larvae. Statistical deifferences have been shown by various letters (Tukey’s test, $p \leq 0.05$ ).

Effect of ions and inhibitors on enzyme activity

Activity of $\alpha$-glucosidase in the gut of $B$ oleae larvae were increased by using concentrations of $\mathrm{Ca}^{2+}, \mathrm{Cu}^{2+}, \mathrm{Fe}^{2+}, \mathrm{Na}^{+}$and $\mathrm{Zn}^{2+}$ but the enzymatic activity significantly decreased in presence of $\mathrm{K}^{+}$ and $\mathrm{Mg}^{2+}$ (Table 2). In case of $\beta$-glucosidase, $\mathrm{Cu}^{2+,} \mathrm{K}^{+}$and $\mathrm{Na}^{+}$increased enzymatic activity and but other ions had adverse effects (Table 3). The effects of several chelating agent were examined to find their possible effects on glucosidase activities in the larvae of B. oleae (Table 4 and 5). Phenanthroline and DTC significantly decrease $\alpha$-glucosidase activity but other compounds had no effect on the enzymatic activity (Table 4). EGTA and EDTA significantly decreased $\beta$ glucosidase activity in the larvae while no effects were observed in case of other compounds. 
Table 2. Effect of specific inhibitors on $\alpha$ glucosidases activity of B.oleae.

\begin{tabular}{|c|c|c|}
\hline compound & concentration & specific activity \\
\hline & $\mathrm{C}$ & $0.074 \pm 0.005 \mathrm{bc}$ \\
\hline \multirow[t]{5}{*}{ DTC } & 2 & $0.159 \pm 0.015 \mathrm{~b}$ \\
\hline & 4 & $0.256 \pm 0.008 \mathrm{a}$ \\
\hline & 6 & $0.155 \pm 0.004 \mathrm{~b}$ \\
\hline & 8 & $0.032 \pm 0.007 c$ \\
\hline & 10 & $0.022 \pm 0.007 c$ \\
\hline \multirow[t]{6}{*}{ Phenanthroline } & $\mathrm{C}$ & $0.134=0.019 \mathrm{a}$ \\
\hline & 2 & $0.084=0.040 \mathrm{ab}$ \\
\hline & 4 & $0.025 \pm 0.006 \mathrm{~b}$ \\
\hline & 6 & $0.077 \pm 0.011 \mathrm{ab}$ \\
\hline & 8 & $0.019 \pm 0.002 b$ \\
\hline & 10 & $0.020=0.007 b$ \\
\hline \multirow[t]{5}{*}{ EGTA } & $\begin{array}{l}c \\
2\end{array}$ & $\begin{array}{l}0.073 \pm 0.007 c \\
0.026 \pm 0.007 c\end{array}$ \\
\hline & 4 & $0.270 \pm 0.019 \mathrm{a}$ \\
\hline & 6 & $0.087 \pm 0.013 c$ \\
\hline & 8 & $0.209 \pm 0.010 \mathrm{ab}$ \\
\hline & 10 & $0.114 \pm 0.109 \mathrm{bc}$ \\
\hline \multirow[t]{6}{*}{ EDTA } & C & $0.029 \pm 0.013 \mathrm{ab}$ \\
\hline & 2 & $0.119 \pm 0.006 \mathrm{a}$ \\
\hline & 4 & $0.038 \pm 0.009 \mathrm{ab}$ \\
\hline & 6 & $0.009 \pm 0.002 \mathrm{~b}$ \\
\hline & 8 & $0.089 \pm 0.014 \mathrm{ab}$ \\
\hline & 10 & $0.077 \pm 0.011 \mathrm{ab}$ \\
\hline \multirow[t]{6}{*}{ TTHA } & $\mathrm{C}$ & $0.052 \pm 0.009 \mathrm{ab}$ \\
\hline & 2 & $0.034 \pm 0.009 \mathrm{~b}$ \\
\hline & 4 & $0.073=0.020 \mathrm{ab}$ \\
\hline & 6 & $0.038 \pm 0.009 \mathrm{~b}$ \\
\hline & 8 & $0.155 \pm 0.009 \mathrm{a}$ \\
\hline & 10 & $0.085 \pm 0.007 \mathrm{ab}$ \\
\hline
\end{tabular}

Table 4. Effect of mono- and divalent actions on $\alpha$-glucosidases activity of B.oleae.

\begin{tabular}{|c|c|c|}
\hline \multirow[t]{2}{*}{ compound } & concentration & $\begin{array}{l}\text { Specific } \\
\text { activity }\end{array}$ \\
\hline & c & $0.025 \pm 0.006 \mathrm{a}$ \\
\hline \multirow[t]{3}{*}{$\mathrm{Ca}$} & 1 & $0.051=0.005 \mathrm{a}$ \\
\hline & 3 & $0.096 \pm 0.017 \mathrm{a}$ \\
\hline & 5 & $0.263 \pm 0.091 \mathrm{a}$ \\
\hline \multirow{4}{*}{$\mathrm{Cu}$} & c & $0.025 \pm 0.003 \mathrm{~b}$ \\
\hline & 1 & $0.246 \pm 0.017 \mathrm{a}$ \\
\hline & 3 & $0.068=0.010 \mathrm{~b}$ \\
\hline & 5 & $0.076 \pm 0.004 b$ \\
\hline \multirow{4}{*}{$\mathrm{Fe}$} & C & $0.027 \pm 0.010 \mathrm{a}$ \\
\hline & 1 & $0.089 \pm 0.013 \mathrm{a}$ \\
\hline & 3 & $0.270 \pm 0.106 \mathrm{a}$ \\
\hline & 5 & $0.405 \pm 0.138 \mathrm{a}$ \\
\hline \multirow{4}{*}{$\mathrm{K}$} & c & $0.181 \pm 0.014 \mathrm{a}$ \\
\hline & 1 & $0.102 \pm 0.013 \mathrm{a}$ \\
\hline & 3 & $0.146 \pm 0.019 \mathrm{a}$ \\
\hline & 5 & $0.070 \pm 0.016 \mathrm{a}$ \\
\hline \multirow{4}{*}{$\mathrm{Mg}$} & c & $0.321 \pm 0.013 \mathrm{a}$ \\
\hline & 1 & $0.010=0.002 b$ \\
\hline & 3 & $0.040=0.015 b$ \\
\hline & 5 & $0.020 \pm 0.007 b$ \\
\hline \multirow{4}{*}{$\mathrm{Na}$} & c & $0.064 \pm 0.013 \mathrm{ab}$ \\
\hline & 1 & $0.018 \neq 0.004 b$ \\
\hline & 3 & $0.116 \pm 0.004 \mathrm{ab}$ \\
\hline & 5 & $0.148 \pm 0.016 \mathrm{a}$ \\
\hline \multirow{4}{*}{$\mathrm{Zn}$} & C & $0.078 \pm 0.019 b$ \\
\hline & 1 & $0.121=0.025 \mathrm{~b}$ \\
\hline & 3 & $0.065 \pm 0.006 b$ \\
\hline & 5 & $0.306 \pm 0.014 \mathrm{a}$ \\
\hline
\end{tabular}

DELKASH-ROUDSARI S. et al.

Table 3. Effect of specific inhibitors on $\beta$ glucosidases activity of B.oleae.

\begin{tabular}{|c|c|c|}
\hline compound & concentration & Specif ic activity \\
\hline \multirow{6}{*}{ DTC } & $\mathrm{C}$ & $0.006 \pm 0.002 \mathrm{a}$ \\
\hline & 2 & $0.084 \pm 0.017 \mathrm{a}$ \\
\hline & 4 & $0.059 \pm 0.006 \mathrm{a}$ \\
\hline & 6 & $0.066 \pm 0.029 \mathrm{a}$ \\
\hline & 8 & $0.059 \pm 0.013 \mathrm{a}$ \\
\hline & 10 & $0.062 \pm 0.008 \mathrm{a}$ \\
\hline \multirow[t]{6}{*}{ Phenanthroline } & C & $0.172 \pm 0.025 \mathrm{a}$ \\
\hline & 2 & $0.176 \pm 0.030 \mathrm{a}$ \\
\hline & 4 & $0.232 \pm 0.017 \mathrm{a}$ \\
\hline & 6 & $0.144 \pm 0.017 \mathrm{a}$ \\
\hline & 8 & $0.120 \pm 0.013 \mathrm{a}$ \\
\hline & 10 & $0.112 \pm 0.007 \mathrm{a}$ \\
\hline \multirow[t]{6}{*}{ EGTA } & c & $0.178 \pm 0.030 \mathrm{a}$ \\
\hline & 2 & $0.030 \pm 0.007 b$ \\
\hline & 4 & $0.091=0.003 \mathrm{ab}$ \\
\hline & 6 & $0.032 \pm 0.006 \mathrm{~b}$ \\
\hline & 8 & $0.098 \pm 0.006 \mathrm{ab}$ \\
\hline & 10 & $0.091=0.002 \mathrm{ab}$ \\
\hline \multirow[t]{5}{*}{ EDTA } & $\begin{array}{l}c \\
2\end{array}$ & $\begin{array}{l}0.135 \pm 0.006 \mathrm{a} \\
0.067 \pm 0.14 \mathrm{a}\end{array}$ \\
\hline & 4 & $0.141=0.004 \mathrm{a}$ \\
\hline & 6 & $0.124 \pm 0.016 \mathrm{a}$ \\
\hline & 8 & $0.109 \pm 0.024 \mathrm{a}$ \\
\hline & 10 & $0.041=0.011 \mathrm{a}$ \\
\hline \multirow[t]{6}{*}{ TTHA } & C & $0.089 \pm 0.027 \mathrm{a}$ \\
\hline & 2 & $0.120 \pm 0.006 \mathrm{a}$ \\
\hline & 4 & $0.105 \pm 0.031 \mathrm{a}$ \\
\hline & 6 & $0.064 \pm 0.002 \mathrm{a}$ \\
\hline & 8 & $0.052 \pm 0.012 \mathrm{a}$ \\
\hline & 10 & $0.086 \pm 0.021 \mathrm{a}$ \\
\hline
\end{tabular}

Table 5. Effect of mono- and divalent actions on $\beta$-glucosidases activity of B.oleae.

\begin{tabular}{|c|c|c|}
\hline \multirow[t]{2}{*}{ compound } & concentration & $\begin{array}{l}\text { Specific } \\
\text { activity }\end{array}$ \\
\hline & c & $0.182 \pm 0.006$ \\
\hline \multirow[t]{3}{*}{$\mathrm{Ca}$} & 1 & $0.164 \pm 0.006$ \\
\hline & 3 & $0.120 \pm 0.021$ \\
\hline & 5 & $0.098 \pm 0.007$ \\
\hline & C & $0.008 \pm 0.003$ \\
\hline \multirow[t]{3}{*}{$\mathrm{Cu}$} & 1 & $0.038 \pm 0.009$ \\
\hline & 3 & $0.098 \pm 0.006$ \\
\hline & 5 & $0.112 \pm 0.034$ \\
\hline & C & $0.260 \pm 0.050$ \\
\hline \multirow{3}{*}{$\mathrm{Fe}$} & 1 & $0.054 \pm 0.019$ \\
\hline & 3 & $0.335 \pm 0.069$ \\
\hline & 5 & $0.170 \pm 0.026$ \\
\hline \multirow{4}{*}{$\mathrm{K}$} & c & $0.071=0.019$ \\
\hline & 1 & $0.075 \pm 0.003$ \\
\hline & 3 & $0.102 \pm 0.007$ \\
\hline & 5 & $0.100 \pm 0.013$ \\
\hline \multirow{4}{*}{$\mathrm{Mg}$} & c & $0.133 \pm 0.011$ \\
\hline & 1 & $0.056 \pm 0.008$ \\
\hline & 3 & $0.278 \pm 0.016$ \\
\hline & 5 & $0.035 \pm 0.008$ \\
\hline \multirow{4}{*}{$\mathrm{Na}$} & C & $0.063 \pm 0.018$ \\
\hline & 1 & $0.217 \pm 0.015$ \\
\hline & 3 & $0.152 \pm 0.014$ \\
\hline & 5 & $0.093 \pm 0.006$ \\
\hline \multirow{4}{*}{$\mathrm{Zn}$} & C & $0.050 \pm 0.015$ \\
\hline & 1 & $0.067 \pm 0.017$ \\
\hline & 3 & $0.032 \pm 0.008$ \\
\hline & 5 & $0.077 \pm 0.020$ \\
\hline
\end{tabular}


Kinetic parameters $\left(V_{\max }\right.$ and $\left.K_{m}\right)$ of $\alpha$ - and $\beta$-glucosidase in gut

The effect of substrate concentrations on enzymatic activity was calculated and kinetic parameters of $\alpha$ - and $\beta$-glucosidases are shown in Figure 3. $V_{\max }$ value of $\alpha$ - and $\beta$-glucosidases were found to be 0.11 and $0.21(\mu \mathrm{mol} / \mathrm{min} / \mathrm{mg}$ protein) and $K_{m}$ values were obtained 4.26 and $0.84(\mathrm{mM})$, respectively (Figure 3).

\section{Alpha-glucosidase}
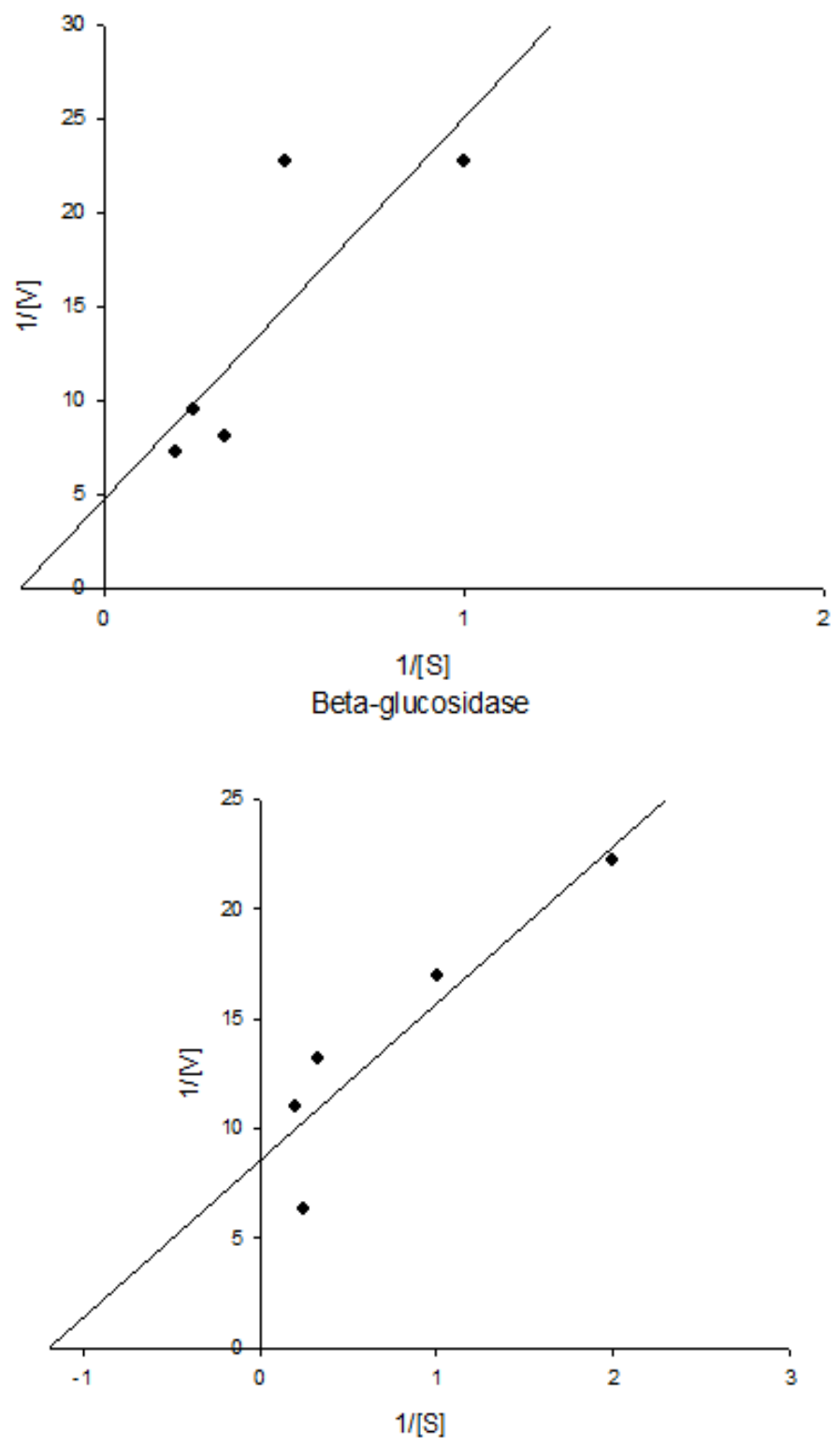

Figure 3. Lineweaver-Burk plots of alpha and beta-glucosidase in gut of B.oleae larvae.

Effect of different varieties on $\alpha$ - and $\beta$ glucosidases

Activities of $\alpha$ - and $\beta$-glucosidase in the larvae fed on Amigdalifolia, Manzallina, Arbequina, Conservalia, Kalamata, Balidi, Zard, Roghani, Shengher, Mari, Fishomi, Frangivento and Coratina varieties of olive have been shown in
Figure 4. The higehst activity of $\alpha$-glucosidase was found in Frangivento and Amigdalifolia varieties but Zard and Conservalia varieties had the significant negative effects on the enzymatic activity (Figure 4). The higehst activity of $\beta$ glucosidase was found in Fishomi variety and the lowest ones have been observed in Zard, Kalamata and Arbequina (Figure 4). 


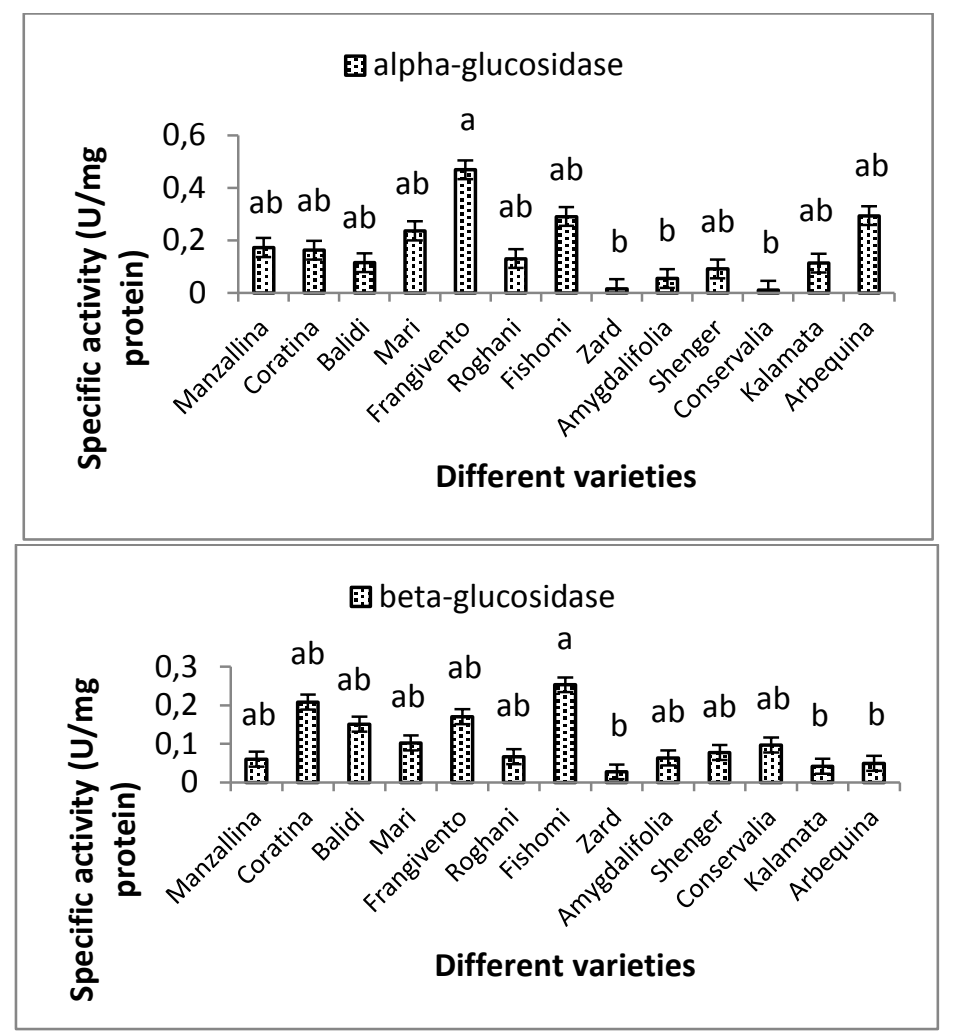

Figure 4. The effect of different varieties on the activities of $\alpha$ - and $\beta$ - glucosidases extracted from the digestive system of B.oleae larvae. Statistical deifferences have been shown by various letters (Tukey's test, $p \leq 0.05$ ).

\section{DISCUSSION}

Glucosidases are the exo-enzymes which hydrolyze glycosyl bonds and release glucose from oligosaccharides (9). On the hand, glucosidases attack to carbohydrates followed by action of endoamylases like $\alpha$-amylase. Since, almost all naturally occurring plant glycosides are $\beta$-linked o-glycosyl it could be concluded that $\beta$-glucosidases are more important than $\alpha$-glucosidases in the metabolism of plant glycosides. Glycosides are the allelochemicals that deal as the defensive compounds in host plant (27). For example, resistance of corn to the European corn borer Ostrinia nubilalis Hubner (Lepidoptera: Pyralidae) is due to presence of a glycoside known as DIMBOA. Also glycosides have antifeedant property against phytophagous insects (9). Hemming et al. (28) have reported that higher amounts of phenolic glycosides cause lower activity of $\beta$-glucosidase in gypsy moth Lymantria dispar (L.) (Lepidoptera: Lymantriidae). Our data clearly demonstrated that $\alpha$ - and $\beta$-glucosidases are present in the digestive system of $B$. oleae larvae. Meanwhile, it was found presence of the enzymes in soluble content of gut rather than membrane-bound samples. It means that these enzymes are free in midgut lumen of larvae and digest oligosaccharides followed by primary digestion of polysaccharides due to $\alpha$-amylase activity. These findings are similar to results of Zibaee (25) on Pieris brassicae L. (Lepidoptera: Pieridae) and Ramzi and Zibaee (29) on Apodiphus amygdali Germar (Hemiptera: Pentatomidae).

Temperature and $\mathrm{pH}$ are the two important factors at biochemical reaction. Our results revealed that $\alpha$ - and $\beta$-glucosidases are active in acidic $\mathrm{pH}$ conditions correspondances with our previous report on $\alpha$-amylase of $B$. oleae (24). Jayme et al. (30) have shown an optimal pH of 5.5 for $\alpha$-glucosidase in Anopheles aquasalis (Diptera: Culicidae). The optimal $\mathrm{pH}$ of $\beta$ glucosidase in larvae of the palm weevil, Rhynchophorus palmarum L. (Coleoptera: Curculionidae) was found at $\mathrm{pH} 5$ (18). Ahsaei et al. (31) reported optimal $\mathrm{pH}$ value of 5 for $\beta$ glucosidase activity in Lixus incanescens adults but no activity of $\alpha$-glucosidase was detected. $\alpha$ glucosidase in Eurygaster integriceps Puton (Hemiptera: Scutelleridae) had acidic range of 4 to 6 (32). Differences in optimal $\mathrm{pH}$ value could be attributed to phylogenetic relationship of species or reaction to different food sources (33). For example, insects fed on tree foliars have highly alkaline $\mathrm{pH}$ in their midgut to overcome toxic materials ingested along with food. Fruits 
DELKASH-ROUDSARI S. et al.

of different olive varieties have a $\mathrm{pH}$ range from 3 to 7 so there might be an adaptability between $\mathrm{pH}$ of fruit tissues and optimal $\mathrm{pH}$ value of $\alpha$ and $\beta$-glucosidases in $B$. oleae larvae (34). Optimal temperatures for $\alpha$ - and $\beta$-glucosidase activities were different for these enzymes which it was found $45^{\circ} \mathrm{C}$ and $25{ }^{\circ} \mathrm{C}$ for $\alpha$ - and $\beta$ glucosidases, respectively. The optimal temperature for the enzymatic activity in $R$. palmarum was between $40^{\circ} \mathrm{C}$ and $50^{\circ} \mathrm{C}$ (18). The optimal activity for $\alpha$ - and $\beta$-glucosidases in rice striped stem borer was found in $45^{\circ} \mathrm{C}$ (13). In Sunn pest, optimal activity of $\alpha$-glucosidase was found between 40 to $45^{\circ} \mathrm{C}$ (Bandani et al., 2010). Increasing temperature causes enzymatic reactions occur faster since enzymes have the temperature above which its structure and activity disrupted $(35,36)$.

Ions are the important factor in active sites of enzymes and serve in several mechanisms. (1) Ions take and release electrons due to activation of electrophiles and nucleophiles, (2) Ions intervene in the reactions of nucleophiles, (3) they can keep enzyme and substrate in close distance through the coordination bonds causing the higher efficiency of enzymatic activity, (4) Ions put active groups of enzyme and substrate in an effective position to elevate efficiency of enzyme-substrate complex or stability of enzyme (37). In our study, different concentrations of ions had various effects on activity of $\alpha$ - and $\beta$ glucosidase activities in larvae of $B$. oleae. Zeng and Cohen (38) reported that $\mathrm{Cu}^{2+}$ had the most effect $(118 \%)$ and $\mathrm{Mg}^{2+}$ showed the least effect (96\%) on $\alpha$ - and $\beta$-glucosidase of Lygus Hesperus Fabricius (Hemiptera: Miridae). Bandani et al. (32) found that $\mathrm{Na}^{+}, \mathrm{K}^{+}, \mathrm{Mg}^{2+}$ and $\mathrm{Ca}^{2+}$ had positive effects on $\alpha$-glucosidase activity of E. integriceps and urea, SDS, Tween 80, Triton X-100 and EDTA had inhibitory effects on enzymatic activity. Valienamine and Validamine inhibited $\beta$-glucosidase in the salivary glands of Reticulitermes flaviceps (39). Chemical agents $\mathrm{CuCl}_{2}, \mathrm{ZnCl}_{2}, \mathrm{FeCl}_{3}$, DTNB and pCMB have an inhibitory effect on $\beta$ glucosidase activity of $R$. palmarum (18). $\mathrm{NaCl}$, $\mathrm{CaCl}_{2}$ and $\mathrm{MgCl}_{2}$ concentrations had positive effects and $\mathrm{KCl}$, EDTA, SDS but Urea had negative effects on enzyme activity of rice striped stem borer (13). $\mathrm{Na}^{+}, \mathrm{K}^{+}, \mathrm{Mg}^{2+}$, and $\mathrm{Ca}^{2+}$ have positive effects on the activity of $\alpha$ glucosidase and $\alpha$-amylase in other insects (40, 41). Ramzi and Zibaee (29) demonstrated that $\mathrm{K}^{+}$and $\mathrm{Ca}^{2+}$ significantly increased $\alpha$ glucosidase activity, $\mathrm{Na}^{+}$had no effect and $\mathrm{Cu}^{2+}$,
$\mathrm{Fe}^{2+}$ and $\mathrm{Mg}^{2+}$ had statistically negative effects in the midgut of Apodiphus amygdali Germar (Hemiptera: Pentatomidae). In case of $\beta$ glucosidase activity, $\mathrm{Ca}^{2+}$ and $\mathrm{Fe}^{2+}$ increased the enzymatic activity in the midgut of $A$. amygdali, $\mathrm{Na}+$ had no effect and other ions significantly decreased it. Terra and Ferreira et al. (5) believe that glucosidases are metalloproteins that require calcium for their activity. Additionally, calcium increases stability of the enzymes from variety of sources in both $\mathrm{pH}$ and temperature extremes. This could be the reason of glucosidase sensitivity to general chelating agents (5).

Kinetic parameters of $\alpha$ - and $\beta$-glucosidase showed that olive fruit fly have $K_{m}$ values of 4.26 and $0.84(\mathrm{mM})$, respectively. These data indicate that $\beta$-glucosidase had higher affinity toward the substrate. So, it can be concluded that $\beta$-glucosidases are more efficient in carbohydrates digestion of olive fruit fly via affinity to substartes. $K_{\mathrm{m}}$ has an inverse relationship with the substrate concentration required to saturate the active sites of the enzyme. The higher value of $K_{\mathrm{m}}$ indicates the lower affinity of enzyme for substrate. In fact, $\mathrm{K}_{\mathrm{m}}$ is the parameter showing stability of the enzyme-substrate complex.

Activities of $\alpha$ - and $\beta$-glucosidase were different in the $B$. oleae larvae fed on various olive varieties. These differences could be attributed to molecular properties of the carbohydrases available in the food and contents of glycosides and phenolic components (42). Hemming and Lindroth (28) indicated that performance of Lymantridat moth is affected variation in levels of phenolic glycosides. These compound significantly decreased larval growth, development and reproductive ability of adults. It is believed that midgut glycosidases e.g. $\alpha$ - and $\beta$-glucosidases are important in metabolizing phenolic glycosides (28). Overall activity of digestive carbohydrases lead to releasing of glucose and bioactivating of toxic $\alpha$-glycones or especially reactive orthoquinone methides (28). These process decrease $\beta$ glucosidase activity to protect larvae from reactive phenolic glycoside metabolites. Hence, the lower activity of glucosidases in Zard variety could be attributed to presence of higher amount of glycosides in fruits.

\section{CONCLUSIONS}

Based on the present study, it can be concluded that glucosidases play an important role in $B$. oleae digestion. The current findings in addition 
to our previous report on amylolytic activity might be useful to design a control procedure by recruiting resistant varieties. Delkash-Roudsari et al. (24) reported that an amylolytic inhibitor from Polyganum persicaria L. caused significant decrease in $\alpha$-amylase activity of $B$. oleae larvae. Meanwhile, it was found that Zard variety caused the lowest activity of glucosidases in the larvae. So, genetic engineering by considering compounds in $P$. persicaria and Zard variety could be promising to provide resistant varieties of olive against the pest. Finally, understanding of digestive enzyme properties, particularly the effect of inhibitors on enzymatic activity and physiology of insects, could be useful to reach safe and useful controls of insect pests before achieving to resistant varieties.

\section{ACKNOWLEDGEMENT}

The research has been supported by a grant of university of Guilan.

\section{REFERENCE}

1. Richard, R. and Phillips, P. A., StewartLeslie, J. and Sibbett, G. S., Olive fruit fly population in central and southern California. $57.2003 . \quad$ Doi: 10.3733/ca.v057n04p122.

2. Zalom, F.G., Van Steenwyk, R. A., Burrack, H. J. and Johnson, M. W., Olive fruit fly. University of California Pests in Gardens and Landscapes, 2009.

3. Mirrahimi, S., Khalaghani, J. and Nouri, H., Effect of time, direction and site of sampling on olive infestation by olive fruit fly. Proceedings of 18th Iranian Plant protection, 2008.

4. Laskowski, J. R. and Kato M, Protein inhibitors of proteinases. Ann. Rev., 49: 593-626, 1980.

5. Terra, W.R. and Ferriera, C., Biochemistry of digestion. In: Gilbert LI, Editor. Insect Molecular Biology and Biochemistry. pp. 365-418. Elsevier, 2012.

6. Terra, W.R. and Ferreira, C., Insect digestive enzymes: Properties, compartmentalization and function. Comp. Biochem.Physiol. Part B., 109: 1-62, 1994.

7. Lagadic, L. and Chararas, C., Etude des activites osidasiques digestives d'adultes de Bruchus afinis en tours d'hivernation en Clevage artificial et en conditions seminaturelles. Entomol. Experim. Appl. 48: 247-255 (1988).

8. Baker, R.J. and Lehner, Y., A look at honey bee gut functions.Bee. J.,112,336-338, 1972
9. Terra, W.R., Ferreira, C., Jordao, B.P. and Dillon, R.J., Digestive enzymes, in: M.J. Lehane, Billingsley, P.F. (Eds.), Biology of the Insect Midgut, Chapman and Hall, London. 153-193: 1996.

10. Silva, C.P. and Terra, W.R., $\alpha$-Galactosidase activity in ingested seeds and in the midgut of Dysdercus peruvianus (Hemiptera: Pyrrhocoridae). Arch. Insect. Biochem. Physiol., 34: 443-460, 1997.

11. Baker, J.E., Properties of glycosidases from the maize weevil, Sitophilus zeamais. Insect. Biochem. 21: 615-621, 1991.

12. Takewaki, S., Chiba, S., Kimura, A., Matsui, H. and Koike, Y., Purification and properties of alpha -glucosidases of the honey bee Apis mellifera L. Agri. Biol. Chem., 44: 731- 740, 1980.

13. Zibaee, A., Bandani, A.R. and Ramzi, S., Enzymatic properties of alpha- and betaglocusidases extracted from midgut and salivary glands of rice striped stem borer, Chilo suppressalis Walker (Lepidoptera: Pyralidae).Comp.Ren.Biol.,332:633-41,2009

14. Darboux, I., Nielsen-LeRoux, C., Charles, J.F. and Pauron, D., The receptor of Bacillus sphaericus binary toxin in Culex pipiens (Diptera: Culicidae) midgut: molecular cloning and expression. Insect. Biochem. Mol. Biol., 31: 981-990, 2001.

15. Janecek, S., Alpha-amylase family: molecular biology and evolution. Prog. Biophys. Mol. Biol., 67: 67-97, 1997.

16. Ferreira, C. and Terra, W.R., Physical and kinetic properties of a plasma-membranebound P-Dglucosidase (cellobiase) from midgut cells of an insect (Rhynchosciara americana larva). Biochem. J.,213: 43-51, 1983

17. Ferreira, A.H., Marana, S.R., Terra, W.R. and Ferreira, C., Purification, molecular cloning, and properties of a $\beta$-glycosidase isolated from midgut lumen of Tenebrio molitor (Coleoptera) larvae. Insect. Biochem. Mol. Biol. 31: 1065-1076, 2001.

18. Yapi, D.Y.A., Gnakri, D., Niamke, S.L. and Kouame, L.P., Purification and biochemical characterization of a specific $\beta$-glucosidase from the digestive fluid of larvae of the palm weevil, Rhynchophorus palmarum. J. Insect. Sci., 8: 65-78, 2009.

19. Rouland, C., Matoub, M., Mora, P. and Petek, F., Properties of two $\beta$-glucosidases purified from the termite Macrotermes mulleri and from its symbiotic fungus, Termitomyces sp. Carbohyd. Res., 233: 237-245, 1992.

20. Matoub, M., La symbiose termite champignon chez Macrotermes bellicosus. 
Thèse de doctorat, Université, Paris Val de Marne, 1993.

21. Kouamé, L.P., Kouamé, A.F., Niamke, S.L., Faulet, B.M. and Kamenan, A., Biochemical and catalytic properties of two betaglycosidases purified from workers of the termite Macrotermes subhyalinus (Isoptera: Termitidae). Inter. J. Trop. Insect. Sci., 25: 103-113, 2005.

22. Pontoh, J. and Low, N.H., Purification and characterization of $\beta$-glucosidase from honey bees (Apis mellifera). Insect. Biochem. Mol. Biol., 32: 679-690, 2002.

23. Marana, S.R., Jacobs-Lorena, M., Terra, W.R. and Ferreira, C., Amino acid residues involved in substrate binding and catalysis in an insect digestive b-glycosidase. Biochim. Biophys. Acta., 1545: 41-52, 2001.

24. Delkash-Roudsari, S., Zibaee, A. and Abbaci Mozhdehi, M.R., Digestive a-amylase of Bacterocera oleae Gmelin (Diptera: Tephritidae): Biochemical characterization and effect of proteinaceous inhibitor. J. King. Saud. Univ. Sci. 26: 53-58, (2014).

25. Zibaee, A., Digestive enzymes of large cabbage white butterfly, Pieris brassicae L. (Lepidoptera: Pieridae) from developmental and site of activity perspectives. Italian. $J$. Zool., 79: 13-26, 2012.

26. Lowry, O.H., Rosebrough, N.J., Farr, A.L. and Randall, R.J., Protein measurement with the Folin phenol reagent. J. Biol. Chem., 193: 265-75, 1951.

27. Hsiao, T.H., Feeding behavior. Comp. Biochem. Physiol. Part C., 9: 471-512, 1985.

28. Hemming, J.C. and Lindroth, R.L., Effects of Phenolic Glycosides and Protein on Gypsy Moth (Lepidoptera: Lymantriidae) and Forest Tent Caterpillar (Lepidoptera: Lasiocampidae) Performance and Detoxication Activities. Environ. Entomol., 29: 1108-1115, 2000.

29. Ramzi, S. and Zibaee, A., Digestive glucosidases in the midgut of Apodiphus amygdali Germar (Hemiptera: Pentatomidae). Arch. Phytopathol. Plant. Protect., 46: 21312138, 2013.

30. Jayme, A., Machado, F.P., Lima, J.B., Valle, D. and Ribolla, P.E.M., Sugar digestion in mosquitoes: Identification and characterization of three midgut $\alpha$ glucosidases of the neo-tropical malaria vector Anopheles aquasalis (Diptera: Culicidae). Comp. Biochem. Physiol. Part B., 147: 993-1000, 2007.

31. Ahsaei, S.M., Hosseininaveh, V. and Bigham $\mathrm{M}$, Biochemical properties of digestive carbohydrases from the sugar beet weevil,
DELKASH-ROUDSARI S. et al.

Lixus incanescens (Coleoptera:

Curculionidae). Arthrop., 2: 126-136, 2013.

32. Bandani, A.R., Kazzazi, M. and Allahyari, M., Gut PH, and Isolation and Characterization of Digestive $\alpha$-DGlucosidase of Sunn Pest. J. Agri. Sci. Tech., 12: 265-274, 2010.

33. Zibaee, A., Bandani, A.R., Kafil, M. and Ramzi, S., Characterization of $\alpha$-amylase in the midgut and the salivary glands of rice striped stem borer, Chilo suppressalis Walker (Lepidoptera: Pyralidae). J. Asia-Pacific. Entomol., 11: 201-205, 2009.

34. Anonymous, Approximate $\mathrm{pH}$ of Foods and Food Products. US FDA/CFSAN. Available at: http://www.cfsan.fda.gov/ comm/lacfphs.html (2007).

35. Agblor, A., Henderson, H.M. and Madrid, F.J., Characterization of alpha-amylase and polygalacturonase from Lygus spp. (Heteroptera: Miridae). Food. Res. Inter., 27: 321-326, 1994.

36. Applebaum, S.W., Biochemistry of digestion. in: Kerkut, G.A., Gilbert, L.L., (Eds.), Comprehensive Insect Physiology, Biochemistry and Pharmacology. Vol.4: Regulation, Digestion, Excretion. Pergamon Press, pp. 279-307, 1985.

37. Zibaee, A., Bandani, A.R., Fazeli-Dinan, M., Zibaee, I., Sendi, J.J. and Maleki, A., A trypsin-like protease in rice green semilooper, Naranga aenescens Moore (Lepidoptera: Noctuidae): purification and characterization. Arch. Insect. Biochem. Physiol., 78: 1-16, 2011.

38. Zeng, F. and Cohen, A.C., Induction of elastase in a zoophagous heteropteran, Lygus hesperus. Ann. Entomol. Soc. America., 94: 146-151, 2001.

39. Xue, Y.P., Jin, L.Q., Liu, Z.Q., Zhang, J.F. and Zheng, Y.G., Purification and characterization of -glucosidase from Reticulitermes flaviceps and its inhibition by valienamine and validamine. Afri. J. Biotechnol., 7: 4595-4601, 2008.

40. Hori, K., Comparative Study of a Property of Salivary Amylase among various Heteropterous Insects. Comp. Biochem. Physiol. Part B., 42: 501-508, 1972.

41. Kazzazi, M., Bandani, A.R. and Hosseinkhani, S., Biochemical Characterization of $\alpha$-amylase of the Sunn Pest, Eurygaster integriceps. Entomol. Sci., 8: 371-377, 2005.

42. Martin, M.M., Invertebrate-Microbial Interactions: Ingested Fungal Enzymes in Arthropod Biology, first ed. Comstock Publishing Associates, Ithaca, 1987. 
